\title{
The Crystal w Londynie - nowy wyznacznik w kreowaniu miast typu smart city?
} The Crystal in London - a new
determinant in creating smart cities?

\begin{abstract}
Streszczenie
Artykuł podejmuje temat idei smart city oraz sposobu jej wdrożenia na przykładzie obiektu firmy Siemens - The Crystal w Londynie. Budynek ten jest jednocześnie obiektem typu smart building, jak i przestrzenią wystawienniczą prezentująca smart city w trzech, powiązanych ze sobą, skalach: mega, makro i mikro. Pierwsza z nich odnosi się do globalnych uwarunkowań kształtujących współczesne miasta, takich jak: coraz szybsza urbanizacja wraz z rosnącym znaczeniem miast, zmiany klimatu oraz zmiany demograficzne. Skala makro odnosi się do współczesnych miast: ich formy urbanistycznej, czy użytych instrumentów planistycznych. Skala mikro akcentuje perspektywę mieszkańca danego miasta oraz postrzeganie przez niego przestrzeni miejskiej. Autor stawia pytanie, czy zastosowana systematyka i zaprezentowane kierunki wdrażania idei smart city opartej na modelu przedstawionym w pawilonie wystawowym firmy Siemens mogą stanowić wyznacznik przy transformacji danego ośrodka.
\end{abstract}

\begin{abstract}
The article tackles a problem of the smart city idea and how it has been implemented on the example of the Siemens' building- The Crystal in London. The building is simultaneously a smart building, as well as an exhibition space presenting the smart city idea in three interconnected scales: mega, macro and micro. The mega area looks at the global megatrends which shape contemporary cities, such as: rapid urbanization with the growing importance of cities; climate change and demographic change. The macro scale refers to contemporary cities: their urban form and planning methods. The micro scale emphasizes the perspective of a inhabitant of a given city and their perception of urban space. The author poses a question whether the applied systematics and the smart city methods presented in the Siemens' building may be a determinant in cities' transformation.
\end{abstract}

Słowa kluczowe: współczesne miasta, smart city, smart building, zrównoważony rozwój, The Crystal Keywords: contemporary cities, smart city, smart building, sustainable development, The Crystal

\section{Wprowadzenie}

Miasto było w historii kolebką cywilizacji i postępu. Obecnie, podobnie jak wszystkie inne instytucje ludzkie, jest ono głęboko uwikłane w najbardziej gruntowne, zasadnicze i daleko siegające przemiany rewolucyjne, jakie kiedykolwiek ogarneły ludzkość. ${ }^{1}$ Mimo że słowa te zostały zapisane ponad pół wieku temu, obecnie wydają się bardziej aktualne niż kiedykolwiek wcześniej. W XXI wieku, często nazywanym wiekiem miast, procesy związane z gwałtowną urbanizacją ${ }^{2}$, zmianami klimatu, zmianami demograficznymi i kurczącymi się zasobami surowców naturalnych odciskają coraz wyraźniejsze piętno na miastach. Można przyjąć aksjomat, że miasta są ośrodkami, które rozwiązują problemy swoich mieszkańców, ale także same w sobie generują szereg wyzwań, którym mieszkańcy muszą stawić czoła.W związku z tym coraz częściej nasuwa się pytanie: Jak powinno wyglądać miasto przyszłości?

\begin{abstract}
Introduction
'The city throughout history has been the cradle of human civilization and progress. To-day, like every other human institution, it is profoundly involved in the deepest and widest revolution ever to overtake mankind.'1 Although these words have been written more than half a century ago, nowadays they seem to be more up-to-date than ever before. In the 21 st century, commonly dubbed the century of cities, processes related to rapid urbanization, ${ }^{2}$ climate change, demographic changes and shrinking natural resources have taken the toll on cities. Undoubtedly, cities are centers which solve their inhabitants' problems. On the other hand cities generate a number of challenges that theirs inhabitants have to face. Therefore, the question: 'What should the future city look like?' seems to be in the spotlight.
\end{abstract}


Najczęstszą odpowiedzią jest: smart city ${ }^{3}$. Mimo coraz większej popularności i dążenia szeregu miast do uzyskania statusu smart city, trudno jest znaleźć jednoznaczną definicję, opisującą czym powinno się charakteryzować się takie miasto. Najczęściej akcentowany jest aspekt technologiczny. W tym kontekście smart city dąży do poprawy jakości życia w miasta rozumianej w kontekście ekonomicznym, politycznym, spotecznym i politycznym; dzięki użyciu powiązań sieciowych i zastosowaniu nowych technologii (ICT) ${ }^{4}$. Miasto tego typu powinno takż wspierać zrównoważony rozwój ekonomicz powinno táż wowych źch zow

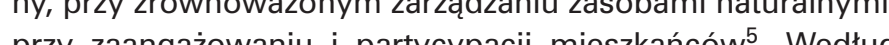
przy zing pomiędzy 6 inteligentnymi składowymi: gospodarka, mobilnością, środowiskiem, ludźmi, życiem i zarządzaniem ${ }^{6}$. Dością, srodowiskiem, ludźmi, życiem i zarządzaniem. zapewnienie inteligentnej jakości życia (smart living), rozu-
mianej jako przyjazne środowisko życia. Zgodnie z definicja R.Giffingera powinno się ono opierać na:

- zapewnieniu dostępu do usług publicznych (funkcji edukacyjnej, kulturalnej i turystycznej)

zdrowych warunków życia (dbałość o środowisko natural-

ne, zapewnienie dostępu do terenów zielonych);

- zapewnieniu wysokiego poziomu poczucia bezpieczeństwa mieszkańców;

- wysokiej jakości zabudowy mieszkalnej

- dążeniu do utrzymania równowagi społecznej.

R.G. Hollands, prowadząc rozważania nad istotą „prawdziwego" smart city, stwierdzit: "Co do zasady, progresywne miasto typu smart city potrzebuje i wymaga wkładu i udziału różnych grup ludzi, a pojęcie smart nie może być być sprowadzone ani do wprowadzania infrastruktury opartej na nowoczesnych technologiach ani do kreowania autopromocyjnych stron internetowych"7. Z architektoniczno-urbanistycznego punktu widzenia miasto stwarza optymalne warunki do życia kiedy jego forma urbanistyczna dopasowana jest do loka, kieuwarunkown Unanco ko: jako umiejetne osadzenie w otaczajacym konteḱcie ojaz jako stworzenie pretekstu do interakcji pomiędzy wielorakimi funkcjami, które miasto powinno spełniać.

Warto podkreślić, że miasta smart city są fenomenem stosunkowo młodym, dlatego idea smart city nie posiada jeszcze jasno określonych ram, w których byłaby zawarta. Każde z miast podejmuje próbe transformacji w kierunku smart city $w$ zróż-

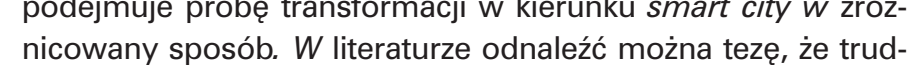
ności w zdefiniowaniu smart city wynikają z głównie "z niedoności w zdefiniowaniu smart city wynikają z głównie "z niedo-
strzegania różnorodności funkcji wysteppujacych w miastach"8. strzegania rożnorodnosci funkcji występujących w miastach ${ }^{\text {. }}$. Autor stawia pytanie, czy zastosowana systematyka i zaprezentowane kierunki wdrażania idei smart city oparte na modelu przedstawiony w pawilonie wystawowym firmy Siemens moga stanowić wyznacznik przy transformacji danego ośrodka. Aby podjąć próbę odpowiedzi na to pytanie, konieczna jest analiza zarówno obiektu, jak i mieszczącej się w nim wystawy.

\section{The Crystal}

Pawilon wystawienniczy The Crystal stał się jednym z symboli Londynu XXI wieku, podobnie jak w połowie XIX w. nieistnie-
The most common answer is: smart city. ${ }^{3}$ Despite the increasing popularity and attempts of numerous cilies to become a smart cily, it is diflicult to find an unambiguous definition what for smart city stands for. Mostly emphasized it the technoto improve the living quality in a city (economic political, social and politicall) by using grid connections and applying new technologies (ICTs). ${ }^{4}$ Such a city should also support sustainable economic growth, with a sustainable management of natural resources, through participatory governance According to Vienna's systematics, the city relies on connections between six smart components: economy, mobility, environment, people, living and governance.

For architects and urban planners, the biggest challenge is to provide the smart living value which According to the definition by R. Giffinger smart living is based on:

- Providing access to public services (educational cultural and touristic function)

Health conditions (care for the environment, ac-

cess to green areas)
High Individual safety

- High housing quality

- Social cohesio

G. Hollands, in his dispute on the essence of the 'real' smart city, came to a conclusion: 'In essence input and contribution of these various groups of people, and cannot simply be labelled as smart by adopting a sophisticated information technology infrastructure or through creating self-promotional websites.' From an architectural and urban poin of view a city provides optimal conditions for living when its urban form is adapted to local conditions. These conditions may be understood in two ways Firstly, as a skillful embedding of architecture in the surrounding. Secondly, as creating a cause for should fulfill.
inteen the multiple functions a city

tively young pointing out that the smart city is relacity idea does not yet have a clearly defined framework. Every single city attempts to transform itself into a smart city in a different way. In the literature one can find the thesis that the difficulty in defining smart city consists mostly of 'not perceiving the diversity of functions occurring in cities" The autho poses a question whether the applied systematics and the smart city methods presented in the transformation. To perform this task it is in cities sity to analyse The Crystal as the building and as The Crystal as the building and as

\section{The Crystal}

The exhibition pavilion, The Crystal, shortly became one of the symbols of 21 st century London nately not preserved, Joseph Paxton's The Crystal Palace. The resemblance of names - The Crystal and The Crystal Palace also seems to intentional. jący juz Pałac Kryształowy Josepha Paxtona. Zbieznośc nazw być nieprzypadkowa. Oba obiekty łączy innowacyjność w odniesieniu do czasów, w których powstały. Jednak dlaczego budynek The Crystal jest istotny w dyspucie na temat smart city? Obiekt firmy Siemens, zaprojektowany przez architektów Wilkinson Eyre można analizować na trzech poziomach jako element składowy miasta- nowy symbol miasta; jako innowacyjny przykład budynku typu smart building $i$ wreszie w najweższym kontekście - jako przestrzeń wystawieszcie prezentującą tematykę smart city.

\section{The Crystal jako element inicjatywy Smart London}

Coraz więcej miast dąży do do uzyskania statusu smart city Nie jest zatem zaskoczeniem, że także najwieksze miasto Euro$\mathrm{py}^{9}$ Londyn, opracowało strategie wdrażania rozwiazań typu smart. Inicjatywa Smart London ${ }^{10}$ zalicza się do długofalowych działań. W tym przypadku transformacja miasta odbywa się w 7 strategicznych obszarach, polegających głównie na:

implementacji nowych technologii i cyfryzaci

- rozwoju zrównoważonego transportu;

zachęcaniu mieszkańców do partycypacji w identyfikowaniu obszarów problemowych w mieście oraz do aktywnego uczestnictwa we wprowadzaniu zmian;

promowaniu używania niekonwencjonalnych źródeł ene gii oraz wprowadzaniu większej niezalezności energetycznej nowej zabudowy oraz rozwiązań redukujących zużycie energii.

Analizując gmach The Crystal1" wyraźnie widać, że budynek zaliczyć można do nurtu smart city. Ponadto, mimo że jes on inicjatywą prywatną, spełnia niemal wszystkie postulaty samorządowego programu Smart London.

\section{The Crystal jako przykład smart building}

$W$ czasach, kiedy dużo słyszymy o zagrożeniach zwiazzanych z postepuiacymi zmianami klimatycznymi, wynikaiacymi z coraz wiekszego zużcia naturalnych surowców, zwiekszajace sie emisii gazów ciep nanionch, czesto zapomina sie o wplywe obieklow bulowlanych na srodowiko. Wedtug dapych zaprezentow bych przez firme Siemens budynki odpowie zaprezew onych przez fir siems budyn odpowie-

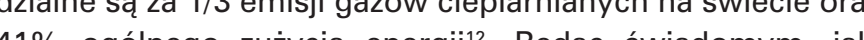
wiply wplyw na srodowisko maja budyni, konieczne jest poszukiwanie nowych roz dących obecnie trendów architektonicznych są budynki typ smart building.

zym właściwie charakteryzuje się obiekt smart building Podobnie jak w przypadku idei smart city, brak jest jednoznacznej definicji. W literaturze fachowej odnaleźć możn szereg definicji, podkreslających wybrane aspekty budynków typu smart building. Budynki te należą do nowej generacj obiektow, opartych na wykorzystaniu technologii teleinformatycznej (ICT) oraz mozzliwości adaptacji do zmiennych warunków ${ }^{13}$. Część definicji akcentuje takze proekologiczny aspekt smart building, ktore powinny dodatkowo dążyć do spełnienia postulatów zrównoważonego rozwoju ${ }^{14}$. Najtrafniejsza, a zarazem najbardziej holistyczna, zdaje się być definicja A.H.
The common feature of both buildings is their innovative characteristic to the times they were designed in. However, why is The Crystal importan in the dispute about smart city? The Siemens' fa cility, designed by Wilkinson Eyre architects, can the city - a new symbol of the city; as an innovative example of a smart building, and finilly, in the narrowest context - as an exhibition space for smart city.

The Crystal as part of the Smart London initiative More and more cities are in pursuit of receiving a 'smart city' status. Therefore, it should come as no surprise that also the largest city in Europe, ing smart solutions. The Smart Londo implementis a long-term strategy. In this case, the transformation of the city focuses on 7 strategic areas, consisting mainly of:

implementation of new technologies and digitization

increasing development of sustainable means of transportation;

encouraging inhabitants to participate in identifying problem areas in the city and to actively participate in implementing changes:

sources, introducing unconventional energy ability of new development and solutions that reduce energy consumption

Analyzing The Crystal1 it is clearly visible that the building may be categorised as a part of the smart city idea. In addition, even though it is a private initiative, it meets almost all requirements of the public Smart London program.

The Crystal as an example of smart building In times when threats of climate change due to the increasing use of natural resources, increasing greenhouse gas emissions is widely discussed, we tend to overlook the environmental impact

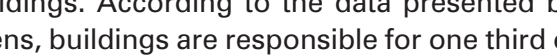
global greenhouse gas emissions and $41 \%$ of total energy consumption worldwide. ${ }^{12}$ Bearing in mind how much buildings impact the environment, it is necessary to search for new solutions for the conis smart buildings.

What exactly is a smart building? Similarly to the mart city idea there is no undisputed definition. There is a number of definitions which highlight the selected aspects of smart buildings. Smart Buildings are part of the next generation of building industry based on the use of ICTs and ability to adapt to changing conditions. ${ }^{13}$ Some of definitions highlights also the ecological aspect of smart building which should meet the demand and the most holitic defintion is the accura sented by AH Buckman, M. Mayfield, S.B. M. Be(2014): 'Smart Buildings are buildings which integrate and account for intelligence, enterprise control, and materials and construction as an 
Buckmana, M. Mayfielda, S.B.M. Becka (2014): Smart Buildings to budynki, które łącza: inteligencję, przedsiębiorczość, kontrolę oraz materiały budowlane $i$ konstrukcje jako integralny system budynku, z możliwością adaptacji, a nie reaktywności, co do zasady, aby przyczynić sie do rozwoju budynku: wydajności energetycznej, długowieczności, komfortu użytkowania i satysfakcji. Zwiększona ilość informacji dostępnych z większej ilości źródet umożliwia adaptacie tych systemów i umożliwi budynkowi Smart Building przygotowanie się do kontekstu i zmian w szerszym spektrum czasowym ${ }^{15}$.

Czym zatem wyróżnia się The Crystal na tle innych budynków typu smart building? Firma Siemens zajmująca się wdrażaniem rozwiązań typu smart we współczesnych miastach ${ }^{16}$ stworzyła budynek-manifest. Obiekt ten jest nie tylko eksponatem , który prezentuje możliwości, jakie można osiągnąć przy wykorzystaniu nowoczesnych technologii (ICT) i zastosowaniu innowacyjnych rozwiazań, ale także laboratorium innowacyjności (living lab), w którym każdy odwiedzający może poznać, czym jest zrównoważony rozwój i dlaczego warto poszukiwać rozwiazań typu smart.

Ten oddany do użytku w 2013 roku budynek, nawiązujący swoim kształtem i dużą ilością przeszkleń do kryształu jest nie tylko architektonicznym wyróżnikiem Londynu. Obiek ten jako pierwszy na świecie uzyskał równocześnie standard LEED Platinum oraz BREEAM Outstanding ${ }^{17}$. Obiekt warto przeanalizować w czterech aspektach: lokalizacji; założen ogólnych dotyczących budynku i jego funkcjonowania; formy architektonicznej oraz zastosowanych innowacji.

Lokalizacja. Położenie budynku nie jest przypadkowe. W bezpośrednim sąsiedztwie znajduje się linia brzegowa Tamizy oraz węzeł komunikacji publicznej. Przy budynku zapewniono stanowiska postojowe dla rowerów, oraz punkty ładowania dla samochodów elektrycznych ${ }^{18}$. Projektanci zadbali, aby do wystawy traktującej o zrównoważonym rozwoju można było swobodnie dotrzeć przy użyciu inteligentnej mobilności (smart mobility) begacej el mentem składowym smart cityZatożenia oǵ́l be Budynek zaprojektowany zosta na zasa Zalożenia ogolne. Budynek zaprojektowany zostal na zasadynek daiy do jak najnizszego zapotzzbowaí nu ze budyest w sta do jak

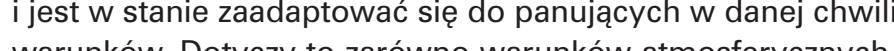
warunkow. Dotyczy to zarown wo par

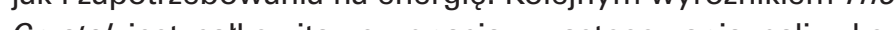
Crystal jest calkowia rezycopalnych. Funkcjonowanie budynku opiera się $w$ pethi na zapotrzebowaniu na energle elektryczna, co wedug firmy Siemens jest kluczowym aspektem dla budownictwa przyszłości

Forma architektoniczna. Analizując elementy wpływające na to, że The Crystal zalicza się do budynków typu smart building należy zacząc od dopasowania bryły budynku do lokalnych warunków. Bryła budynku jest silnie zgeometryzowana i w swojej formie przypomina kryształ. Kształt budynku zosta dokładnie przemyślany - nie jest wyrazem ściśle artystycznej wizji projektantów. Dzięki zastosowaniu skośnych ścian i przemyślanemu rozmieszczeniu przeszkleń, można było zapobiec przegrzewaniu się wnętrz w lecie i odpowiednio nasłonecznić je w zimie. entire building system, with adaptability, not reactivity, at the core, in order to meet the drivers for building progression: energy and efficiency longevity, and comfort and satistaction. The in wider range of sources will allow these systems this become adaptable, and enable a Smart Building to prepare itself for context and change over all to prepare itsert

So what distinguishes The Crystal from other smat buildings? Siemens, which is actively involved in the implementation of smart solutions in contemporary cities, ${ }^{16}$ has created The Crystal- its manifesto. It is not only an 'exhibit' which presents the ern ICTs and innovative solutions, but also it is a living lab where each visitor can learn about sustainable development and why it is worth searching for 'smart' solutions.

This crystalline shaped building is not only a London's landmark. The building is the first in the world to achieve simultaneously standard of LEED Platinum and BREEAM Outstanding. ${ }^{17} \mathrm{It}$ is worth to analyse the building in four aspects: location; main architectural form and applied innovations. Location. The location of the building is not accidental. The building has been erected in proximity to Thames riverfront and the public transport hub. Near the building there are parking stands for bicycles and e-vehicle charging points. ${ }^{18}$ The architects made sure that the building housing the exhibitio about sustainable development may be easily acelement of smart city.

reductive and responsive principles ${ }^{19}$ That meand the building adapts to need as less energy as possible according to the given conditions. This ap plies both to atmospheric conditions and to energy demand. Another distinguishing feature of The Crystal is no fossil fuels use rule. The build ing design is based only on electricity demand, the future development in order to fight against greenhouse effect.

Architectural form. What makes The Crysta a smart building is its adjustment to the local conditions. The building form is highly geometric and resembles a crystal. The building envelope was carefully thought out and is not an outcome of strictly artistic vision of the designers. Thanks to sloping walls and careful use of glass it was posthe summer and to adequately sunbath them in the winter

Applied innovations. The innovation of the building consists on both the use of ICTs and the ecological approach. Unconventional energy sources depend on changeable atmospheric conditions. This is why the building regulates the energy demand according to the amount of resources available in order ity to adapt is enabled by the use of solar panels and innovative ground source heating system. The excess heat from summer is stored in the under-
Zastosowane innowacje. Innowacyjnośc budynku dotyczy zaekologicznego podejścia. Niekonwencjonalne źródła energ zależą od zmiennych warunków atmosferycznych, dlatego budynek reguluje zapotrzebowanie na energię $w$ zależności od ilości dostępnych zasobów, aby stale utrzymywać je na możliwie najniższym poziomie. Adaptacja ta możliwa jest dziekki zastosowaniu paneli słonecznych oraz ogrzewaniu budynku prze innowacyjy system ogrzewania podziemnego loround source heatingl. Polega on na przechowywaniu nadwyzek ciepource heating. Polega on na przechowywaniu nadwyzek ciepła uzyskanych woś wosci wy wienty zapotrzebowanie jest wikszén można zalczyć do obiekow typu smart grid ready. Możliwoś regulacjizaper ki polączenu transmisji danych pomiędzy kilkoma tysiącam sensorów . Dzięki zintegrowanemu zarządzaniu poszczególnymi elementami budynek może samoczynnie zredukować iloś energii elektrycznej dostarczanej do poszczególnych pomieszczeń budynku, bez spadku komfonu uzykowników oblektu. Do najważniejszych rozwiązań proekologicznych zaliczyc można zastosowanie paneli slonecznych oraz racjonaln gospodarkę wodną budynku. Zastosowane na dachu dwa rzędy paneli słonecznych częściowo przetwarzają energie słoneczną na energię elektryczna, potrzebną do funkcjonowania obiektu; częściowo służą do ogrzewania ciepłej wody² Obiekt bazuje na wielokrotnym użyciu wody, w tym głównie wody deszczowej, ktora gromadzona jest w podziemnyc zbiornikach. W efekcie budynek zużywa $90 \%$ mniej wody niż porównywalne konwencjonalne obiekty.

Ponadto, cechą charakterystyczną The Crystal jest możliwośc interakcji pomiędzy budynkiem a jego użytkownikami. Zwiedzający mają możliwość zaobserwować, ile wody i energi elektrycznej budynek zużywa w danej chwili. Dane wyświetlane są na interaktywnych tablicach (aktualizacja odbywa sie 015 minut). Dzieki tej interakcii zwiedzajacy moga uczć sie rozsądnie gospodarować surowcami naturalnymi.

\section{The Crystal jako przestrzeń wystawiennicza}

The Crystal w kontekście wystawienniczym traktuje idee smart city w ujęciu holistycznym. Jest to największa na świecie wystawa poświęcona zrównoważonemu rozwojowi urbanistycznemu²2. Motywem przewodnim wystawy sa trzy, oddziałujące na siebie wzajemnie, skale: mega, makro i mikro. Twórcy wystawy wyznaczyli trzy główne fundamenty zrównoważonego miasta : jakość życia, ekonomię i środowisko które powinny być zbalansowane dzięki właściwemu zarządzaniu. Na powyższej systematyce oparte zostały poszczególne ekspozycje. Sposób prezentacji przyjęty przez twórców wystawy zdaje się być syntezą założeń R. Gifingera, opisanych we wprowadzeniu do artykułu.

najszerszej perspektywie wystawa przedstawia globalne uwarunkowania kształtujące współczesne miasta, takie jak: coraz bardziej postępująca urbanizacja wraz z rosnącym znaczeniem miast, zmiana klimatu oraz zmiany demograficzne. Ważnym elementem jest poszukiwanie odpowiedzi, w jaki sposób przeciwdziałać tymże negatywnym zjawiskom. ground system and drawn back out in the winter when the energy demand is higher. Thanks to such solutions, the building can be classified as 'smart grid ready'. The reductive-responsive principle is possible thanks to interaction of over a few thouand data connections.

The control system enables the building to autoered to a certain part of the building without negative impact on the building's users.

The use of solar panels and the rational water manggement in The Crystal play a big role on the building's sustainability. The two rows of solar panels on the roof partially convert the solar energy into electrical energy necessary for the building; partially are used as hot water heating." The Crystal's water supply and sewage disposal system is which is reccamud use of water, mainly rainwater, As a result the building consumes $90 \%$ less water than comparable conventional facilities.

Moreover, The Crystal's key feature is the interaction between the building and its users. Visitors have the opportunity to observe how much water and electricity the building consumes at a give moment. The data on energy and water consumption is displayed on interactive boards (updated every 15 minutes). Thanks to this interaction, visors may learn to reasonably manage natural re-

The Crystal as an exhibition space

The Crystal as an exhibition space approaches the smart city idea holistically. It is the world's largest exhibition devoted to sustainable urban development. ${ }^{22}$ The exhibition presents the smart city micro. The exhibitors have identified thro main foundations of a sustainable city: quality of life, economy and the environment, which should be balanced through proper governance. The particular exhibitions are based on this systematics. The presentation methods seem to be a synthesis of $\mathrm{B}$. Gifinger's assumptions which are described in the introduction to the article.

The mega area looks at the global megatrends which shape contemporary cities, such as: rapid urbanization with the growing importance of citWhat climate change and demographic change. to alleviate cities' degradation processes.

The macro scale refers to contemporary cities: urban form and planning methods. The most im portant question is: "How should we design citpes now and in the future?". Analyzing the issue of smart city, there is strong tendency to tackle problems of contemporary cities with implementof infrastructure, it is not sufficient to optimize entire city. The real problems of cities would re-

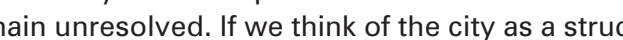
consisting of two basic interacting system : urban and social, ${ }^{23}$ it becomes clear how much 
Skala makro odnosi się do współczesnych miast: ich formy urbanistycznej, czy użytych instrumentów planistycznych. Na pierwszy plan wysuwa się pytanie: „W jaki sposób powinniśmy projektować miasta obecnie i w przyszłości?". Analizujac zagadnienie smart city, można odnieść wrażenie, że większośc działań skupia się rozwiazzywaniu problemów współczesnych miast przez wdrażanie technologii ICT. O ile technologia teleinformatyczna sama w sobie może zoptymalizować dziatanie wybranych aspektów miast np. transportu mieiskiego, czy popraw funkcjon poprawz farkejon w szerszym kontekście. Reane probest miast pozostaja w dalszym ciagu nierozerane jeżli po dejdziemy do mo jako struktury sktadajacej siez z do dejdziezy do miata jak podstawy do mila systa ja stow, odzila jacych na siebie wzajem-

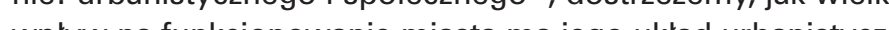

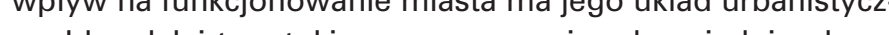
ny. Idąc dalej tym tokiem rozumowa jia odpowiednie, dopasowane do danej lokalizacji środki planistyczne oraz forma urbanistyczna sa warunkiem sine qua non dobrze funkcjonującego miasta. Warto zauwazyc, ze w kontekście idei smart city wystawa jako jedna z pierwszych podkreśla sensu largo wpływ urbanistyki na miasta.

Skala mikro akcentuje perspektywę mieszkańca danego miasta oraz postrzeganie przez niego przestrzeni miejskiej. Głównym zagadnieniem jest pytanie, jak powinno wyglądać nasze życie w przyszłości i w jaki sposób jednostki mogą przyczyniać się do zachowania zrównoważonego rozwoju, a w efekcie oddziaływać na urbanistyke.

\section{Podsumowanie}

$Z$ definicji miasta nie są statyczne. Stale adaptują się do nowych warunków, aby zapewnić jak najlepszą przestrzeń do życia dla swoich mieszkańców. Według H. Van Beurden istnieją trzy elementy potrzebne do stworzenia smart city: wizja (rozwoju miasta): ludzie (którym miasto ma służyc) i proces (sposob w jaki miasto dopowuje do potrzeb swoich mieszkańców ${ }^{24}$. Obiekt The Crysta/jest manifestem zarówno architektonicow jaki wystawienniczym, odpowia

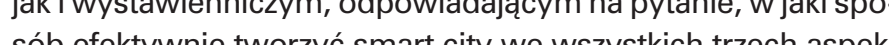
tach. Smart jest

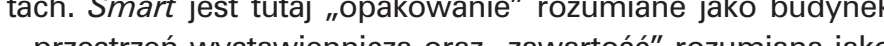

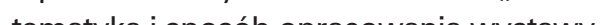

traktowana holistycznie. Inicjatywa wychodzi poza ramy charakterystycznego dla Europy podejścia do miast smart city, osadzającego się na propagowaniu proekologicznego podejścia do architektury i urbanistyki, głównie dotyczącego zrównoważonego transportu i inwestycji w efektywność energetyczną ${ }^{25}$. Najważniejszym wyróżnikiem The Crystal jest podkreślenie roli urbanistyki, środków planistycznych i planistów w tworzeniu miast przyszłości, które w dyspucie o smart city były do tej pory marginalizowane.

Celem artykułu była odpowiedź na pytanie, czy The Crystal stanowi ważne ogniwo w poszukiwaniu optymalnego modelu smart city. Odpowiedź jest jednoznaczna - budynek stanowi nowy wyznacznik dla transformacji miast w kierunku idei smart city. influence urban planning has on the way a city ning methods and urban form is a sine qua no condition of a well-functioning city. It is worth noting that the exhibition housed in The Crystal in terms of the smant city idea design on a cily The micro scale emphasizes

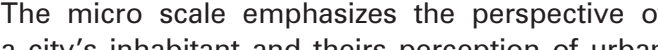
space The focal point is the perception of urban ture life should look like?'. The other issue is how individuals can contribute to sustainable development and, consequently, affect urbanisation.

\section{Summary}

By definition a city cannot be static. Cities are constantly adapting themselves to new conditions their in to provide possibly bo there are three key elements crucial to create a smart city: vision (in what direction a city should be developed): people (whom a city serves) an process (by what means a city may adapt to the needs of its inhabitants). ${ }^{24}$ The Crystal is both an architectural and exhibitional manifesto that presents an answers to the question how to effectively create a smart city in terms of all three aspects. As smart may be described both the 'packaging understood as the building -the exhibition space the exhibition and the way it tack the subject of smart city.

Moreover, the idea of smart city is treated holistically. The initiative goes beyond what is typical for European approach towards smart city - ecologica approach towards architecture and urban planning Whith the main focus on sustainable transportation and investments in energy efficiency sector. ${ }^{25}$ The distinguishing feature of the Crystal is its emphasis on the importance of urban planning, planning mes. The ind masterplo urb in smart city disputes.

whether The Crystave is to provide an answer a search for an optimal smart city model. The an swer is clear - the building sets out a new standard to cities' smartification

ENDNOTES

The sentence beginning The Declarafion of Delos, which
was proclaimed in 1963, during so-called Meeting in Delos (Greece) [in: Wrana J. 2002, p. .53 in $201454 \%$ of world population lived in cities. The forecas esteemates that in 2050 the number of cities' inhabitants
will double to 6.9 bilion people. - World Migration Repor 2015 ${ }^{3}$ Hollands R. .2008; Hall R.E., 2000, Caragliu A., Del Bo C Hollands R.G., 2000.
Nikamp P., 2009
4 Hollands R.G., 2008

${ }_{6}^{5}$ Caragliu A., Del Bo C., Nijkamp P., 2009
6 The author refers to the definition

chers under the direction of R.Gifition performed by resear Technische Uncersitat in Viennal). The researchers study European smart
vers the citites - Giffinger R., et al., $2007 \mathrm{p}$.

${ }^{8}$ Stawasz D., sikora-Fernandez D., Turała M., 2012, p.3
PRZYPISY

'Slowa rozpoczynajace deklaracieje przyjetta w 1963 r. podczas tzw. Sympozju 2 Wedtug raportu Miedzynarodowejej Organizacja ds. Migraciji (IOM) w 2014
roku na swiecie miasta zamieszkiwato $54 \%$ populacij. Prognozy przewiduia, ze w 2050 roku liczba mieszkańcó́ miast podwoi się i będzie wynosić 6.9 miliard Hollands R.G., 2008; Hall R.E., 2000, Caragliu A., Del Bo C., Nijkamp P., 2009
Hollands R., 2008

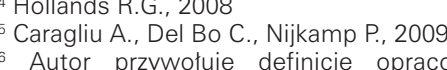

R.Giffingera prowadzacych badania nad europejskimi smart city na Universyyte cie Telchnicznym w Wiedn
'Hollands R.G., 2008, 3.316

.

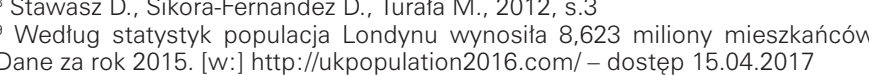

" https://Www. Iondon.gov.uk- dostepp 1.04.2017

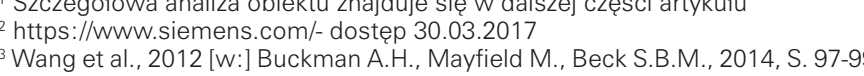
14 Ibidem
5 Trumaczenie autorskie. Z Buckman A.H., Mayfield M., Beck S.B.M., 2014.
s. 98.99

16 Obszar dziatalności firmy skupia sie zarówno na obiektach kubaturowych
(smart building), jaki i na rozwoju nowoczesnych technologii stużacchy zarzadza nim min. ruchem kotowym, infrastruktury (smart mobility
17 Pires de Miranda P., Powell M. at al., 2013, s.73. Warto dodać, że sa to dwa mu. Certyikat $B E E D$ przyznawany jest przez amerrkańskie U.S. Green Building
Council (USGBC), natomiast certyfikat BREEAM przez brytyjskie BRE (Building

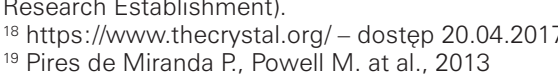

20 biddem
21 Pires do Miranda P., Powell M. at al., 2013, s.73. Energia stoneczna poknywa
$60 \%$ zapotrzebowania budynku na ciepta wode oraz zapewnia ok. 115 zapotrze-
. $60 \%$ zapotrzebowania budynku
bowania un energię elektryczna

${ }_{2}^{2}$ Ibidem
${ }_{23}$ Wallis A., 1977, s.79

23 Wallis A., 1977 , s.79
24 Van Beurden [W:] Manville et al., 2014, s. 78
25 Stawasz D. Sikora-Fernandez D., Turata M. 2012

LITERATURA

11) Buckman A.H. Mayfield M., Beck S.B.M. What is a Smart Building?, Smart
and Sustainable Built Environment, Vol. 3 l Issue: 2, 2014, s. 92-100

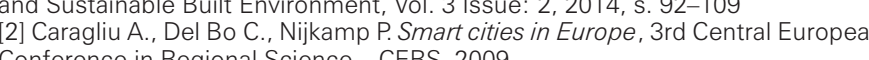
3] Hall R.E. The Vision of $A$ Smart City. 2 nd

nal Life Extension Techno[4] Hollands R.G., Will the real smart city please stand up?, City:analysis of urban

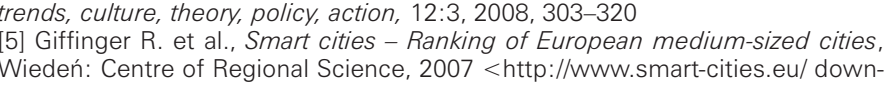

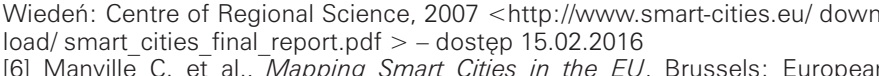

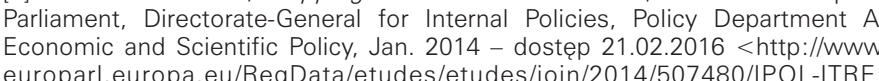

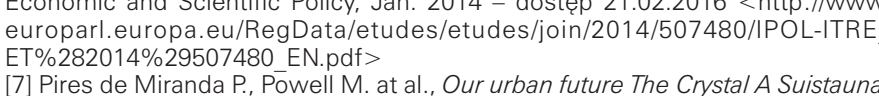

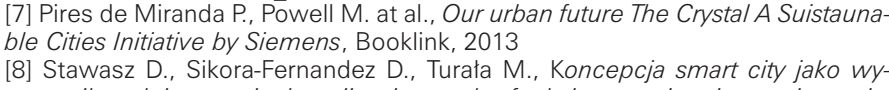

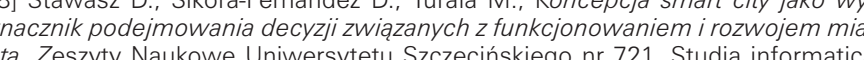
sta, 2 eszyty
$n$ n 29,2012

[9] Wallis A. Miasto i przestrzeń. PWN. Warszawa 1977
(10] World Migration Report 2015[W:] International Organization for Migration

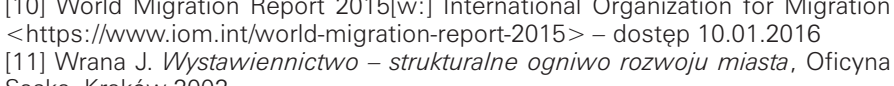
Saska, Kraków 2002

[12] Van Beurden H. Dynamics of Smart Cities: Inspiring Views from Experts Ac-
poss Europe. Amsterdam 2011

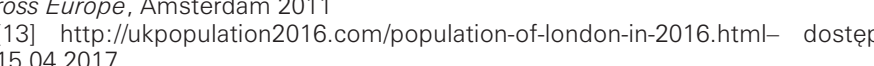
(14) https://Www.london.gov.uk- dostep 1.04.2017

-infrastructure.html- dostep 30.03 .2017
[16] https://www.thecrystal.org - dostęp 20.04.2017
9According to the statistics the population of London con-
sists of 8,623 milion inhabitants. The data accurate for 2015 . in: hittp: ///kpopulation 2016 .com/-access on 15.04201

"Detailed analysis in the further part of the article (2https://www.siemens.com-access on 30.03.2017

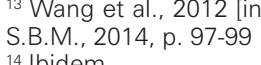

Translation into Polish by the author. Buckman A.H., MayThe firm focuses on both archite

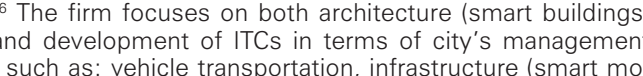
"Pires de Miranda P., Powell M. at al., 2013 , p.73. It is
worth mentioning, the LEED and BREEAM certificates are the most prostigious ones worldwide in terms of sustaina-
ble develooment. The LEED certificate is granted by U.S ble development. The LEED certificate is granted by U.S.
Green Building Council (ESGBC) and the BREEAM certifica-

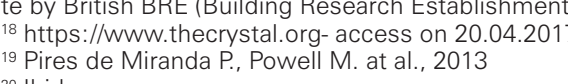

21 Pires de Miranda P., Powell M. at al., 2013, p. 73. Solar hot water heating provides for $60 \%$ of the building demand
for hot water. Solar panels meet about $1 / 5$ demand of the building demand for electricity.

${ }_{23}^{23}$ Wallis A., 1977 , p.79

${ }^{24}$ Van Beurden lin:l Manville et al., 2014, p. 78
${ }^{25}$ Stawasz D., Sikora-Fernandez D., Turata M., 2012

BIBLIOGRAPHY

[1] Buckman A.H., Mayfield M., Beck S.B.M., "What is

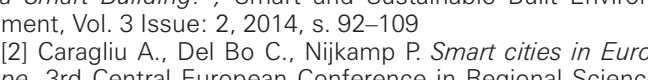
- CERS, 2009 TH [3] Hall R.E., The Vision of A Smart City, 2nd International
Life Extension Technology Workshop, Paris, France, wrze-
sień 2000 . [4] Hollands R.G., Will the real smart city please stand up?
City:analysis of urban trends, culture, theory, policy, action, 12:3, 2008, 303-320 [5] Giffinger R. et al., 2007 Smart cities - Ranking of Europeties final report.pdf $>$ - dostepp 15.02.2016
[6] Manville C. et al., 2014, Mapping Smart Cities in the EU,

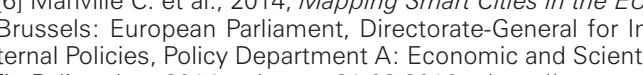
fic Policy, Jan. 2014 - dostep 21.02.2016 <http://Www.eu-
roparl.europa.eu/RegData/etudes/etudes/join/2014/507480/

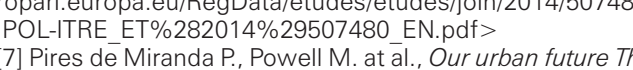
(7) Pires de Miranda P. Powell M. at âl., Our urban future The
Crystal A Suistaunable Cities Initiative by Siemens, Booklink. [8] Stawasz D., Sikora-Fernandez D., Turała M., Koncepcja smart city jako wyznacznik podejmowania decyzii zwizza-
nych z funkcionowaniem irozwojem miasta, Zeszyty Naukowe Uniwersytetu Szczecińskiego $\mathrm{n} \mathrm{r} 721$, studiai informatica

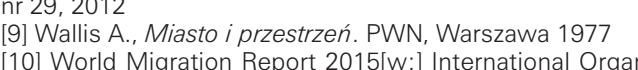
zation for Migration <https://Www.iom.int/world-migration-eport-2015>- dostep 10.01.2016 woju miasta, Oficyna Saska, Kraków 2002 struktura ogniwo roz [12] Van Beurden H. Dynamics of Smart Cities: Inspiring
Views from Experts Across Europe, Amsterdam 2011 [13] hitp: //ukpopulation 2016. 6 . Amm /population-of-london-in-2016.htm/- dostep 15.04.2017
[14] https://www london. gov.uk- dostep 1.04.2017

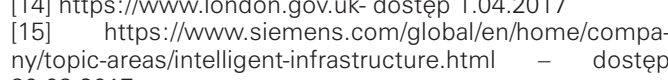
[16] https://www.thecrystal.org - dostęp 20.04.2017 